\title{
Interviewers' Characteristics and Post-Hire Attitudes and Performance
}

\author{
Hussein Ismail \\ Lebanese American University \\ E-Mail: hismail@lau.edu.lb \\ Silva Karkoulian \\ Lebanese American University \\ E-Mail: skarkoul@lau.edu.lb
}

\begin{abstract}
Many studies have demonstrated the impact of interviewers' characteristics on applicants' reactions in terms of their impressions of the organization and their intentions to accept the job offer. However, previous research has generally neglected the effect of interviewers' characteristics on applicants after they join the firm. The present study, which involved a sample of 200 employees from different industries, showed that interviewers' characteristics significantly affect applicants' job satisfaction, motivation, and performance after they were hired in the firm. However, the results did not show support for the proposed effect of interviewers' characteristics on organizational commitment. Discussions and conclusions are presented.
\end{abstract}

Keywords: Recruitment, Applicant Reactions, Interviewer Characteristics, Post-Hire Attitudes, Recruiter

\section{INTRODUCTION}

The recruitment interview continues to be the primary method by which organizations evaluate potential applicants (Posthuma et al., 2002). As a selection tool, the employment interview plays a major role in identifying productive employees and is considered of vital importance for survival today in light of increasing competition and uncertain environments (Michaels et al., 2001; Smart, 1999). It follows that the firm's interviewer who interviews the job candidates who apply to the firm is at the center of this activity. He or she has a major task to convince and attract candidates to work at the firm. The interviewing approach followed by the recruiter is considered 
essential in attracting employees to join the organization (Rynes et al., 1991). For example, studies have shown that the interviewer's personality significantly affects the applicants' overall perceptions of the firm and their decision to accept the job offer (Harris \& Fink, 1987). The interviewers' characteristics, including manners, friendliness, and personal knowledge, have an influence on attraction and job choice intentions (Carless \& Imber, 2007). For instance, research shows that interviewers demonstrating a warm and friendly personality during the interview increase applicants' motivation to pursue the job (Chapman et al., 2005). Although previous research has confirmed that the interviewer's characteristics have an effect on whether employees will join the firm (i.e., before they are hired), previous studies have neglected employee behavior and attitudes after they are hired. Therefore, research needs to investigate the effects of recruiter characteristics on post-hire attitudes and performance (e.g., Hausknecht, Day, \& Thomas, 2004). In fact, what happens after they join the firm, in terms of their attitudes and behavior, is critical to the effectiveness of the organization.

The aim of this study is to examine the impact of interviewers' characteristics on (a) job satisfaction, (b) motivation, (c) commitment, and (d) performance of employees. The paper aims to increase our understanding of the relationship between the recruiter and employees' reactions after they join the firm. The paper begins with a literature review on interviewers' characteristics and applicants' reactions, followed by a review of attitudes and performance and ending with the hypotheses of this study. Next, the methods will be presented. The subsequent sections focus on the results, discussion, and implications.

\section{THEORY AND HYPOTHESIS}

\section{Recruiter Characteristics}

Recruiters can influence how job applicants perceive the firm and their intentions to join the firm. It has been argued that applicants perceive recruiters as representing the character of the entire company (Odiorne \& Hann, 1961). Evidence shows that recruiters exhibiting positive characteristics, such as being warm, friendly, and helpful during the interview, can influence applicants' perceptions (Carless \& Imber, 2007; Goltz \& Giannantonio, 1995; Schmitt \& Coyle, 1976; Turban \& Dougherty, 1992). In the context of recruiter characteristics, these reactions have generally been viewed in terms of the applicants' intentions to accept the job offer and their overall impressions of the job and/or the company (e.g., Harris \& Fink, 1987).

A recent meta-analysis demonstrated that recruiters' characteristics are significantly associated with job pursuit intentions and overall impressions of the 
company and the job (Chapman et al., 2005). In other words, applicants who perceived the interviewer favorably had a high inclination to pursue the job by, for example, submitting an application, attending a second interview, or remaining in the applicant pool. In fact, the recruiter's personableness was a strong predictor of job pursuit intentions $(P=0.50)$. Moreover, all recruiter characteristics, including personableness, trustworthiness, competence, and informativeness, were associated with overall impressions of the organization, with rhos ranging from .26 to 42 . Applicants who viewed recruiters as having positive characteristics also formed overall favorable impressions of the firm. These findings echo previous studies that examined the impact of recruiters' characteristics on applicants' reactions. For example, a study by Harris and Fink (1987) involving 145 subjects found a significant relationship between the former and the likelihood of joining the firm as well as perceptions of the job. In the study, recruiter characteristics were measured using four components: personableness, competence, informativeness, and aggressiveness. Accordingly, in terms of specific recruiter characteristics, personableness was the only characteristic associated with intentions to accept the job offer. In other words, recruiters who have a warm and friendly personality had an effect on whether applicants actually accepted the job offer. Regarding the other dependent variables related to perceptions of the job and the company, personableness and informativeness were mostly associated with perceptions of the job, while personableness, informativeness, and competence were related to perceptions of the company. Here too, the recruiter having a warm personality, offering information about the job, and being knowledgeable all seemed to have an impact on applicants' impressions of the job and the firm overall. On the other hand, aggressiveness, which suggests an unconstructive recruiter attitude, was negatively related to perceptions of the job. Put simply, recruiters who were perceived as hostile led to negative perceptions of the job in the study. Finally, a study by Taylor and Bergmann (1987) also revealed the importance of the recruiter's characteristics in affecting applicants' perceptions in the employment interview. Based on a sample of 1,286 applicants, the authors were interested in examining applicants' reactions to the different recruitment activities they go through across a multi-stage recruitment process. Their results showed that recruiters' empathy, measured in terms of how recruiters show a personal interest in learning about the applicant during the interview, was the strongest predictor of applicant reactions in the early stages of recruitment. In particular, across all other independent variables (e.g., recruiters' age, race, sex, and recruiting experience), the applicants' perceptions of the recruiters' behavior had the strongest impact on the overall impressions of the firm and intentions to accept job offers in the initial stages 
of recruitment. In sum, the papers reviewed herein demonstrate the importance of recruiters' characteristics in applicants' attitudes and behaviors exemplified in the impressions they form toward the firm and in their intentions to accept the job offers.

One explanation for the identified results lies in the signaling theory (Spence, 1973). Due to the limited information that applicants have about the job and the firm (Rynes et al., 1991), applicants might interpret interviewer behavior as signals and cues regarding the organization itself (Rynes \& Miller, 1983). Having said this, applicants who view their recruiters as friendly tend to develop favorable attitudes toward the firm and form positive reactions (Turban \& Dougherty, 1992). Furthermore, the idea that recruiter characteristics have an impact on attitudes and behavior is supported by social exchange theory (Blau, 1964), which suggests that employees who perceive supportive organizational actions toward them will reciprocate back with positive attitudes and behavior (Shore \& Wayne, 1993; Hannah \& Iverson, 2004). In this context, job applicants who receive favorable treatment from recruiters will give back to the organization with positive attitudes and actions toward the organization. Although there is considerable research that demonstrates the influence of the recruitment process on applicants' reactions during the application process (e.g., Taylor \& Bergmann, 1987), research has neglected investigating applicants' attitudes and behavior after they join the firm. Evidence shows that recruiters' characteristics do affect applicants' reactions in the pre-employment stages, as reflected by their impressions and job acceptance, but there is much less knowledge about post-hiring reactions. There have been calls for research in the literature to examine the perceptions and behaviors of the hired persons on job satisfaction, commitment, and performance (Hausknecht et al., 2004). For example, perceptions of the selection process and fairness were expected to have an impact on the work behavior of the hired person (Gilliland, 1993). However, with few exceptions (Gilliland, 1994; Robertson, et al., 1991), Gilliland's (1993) proposition remains largely untested (Hausknecht et al., 2004), which reflects the lack of research in this area (Imus \& Ryan, 2005). This is also in line with Hausknecht et al. (2004, p. 668), who argued that "one important research need in moving forward in the applicant reactions literature forward is to systematically evaluate these post hire attitudinal and behavioral outcomes." The present study aims to advance the knowledge in this area of post-hire reactions in general and the effects of applicant perceptions of recruiters in particular by examining the relationship between recruiters' characteristics and the hired individuals' attitudes and performance. To the researchers' knowledge, no previous study has examined the effects of recruiters' characteristics on hired persons' attitudes and behaviors. This study examines the impact of recruiters' characteristics 
pertaining to the elements of empathy, manners, aggressiveness, knowledge, and competence on the hired individuals’ attitudes and behaviors (Schmitt \& Coyle, 1976). In the current study, attitudes and behavior represent job satisfaction, motivation, commitment, and performance.

Based on the signaling (Spence, 1973) and social exchange theories (Blau, 1964), the researchers hypothesized that positive recruiter attitudes have an impact on job satisfaction, motivation, commitment, and performance. Hired applicants who receive favorable treatment on the part of the recruiters will send positive signals to the hired applicant, who will form and give back with positive actions and attitudes toward the firm (e.g., Carless \& Imber, 2007; Rynes \& Miller, 1983). In what follows, a review of job satisfaction, commitment, motivation, and performance will be presented.

\section{Job Satisfaction}

Job satisfaction is one of the most studied variables in organizational psychology and organizational behavior. An estimated more than 5,000 articles were written on the subject between 1957 and 1992 (Cranny et al., 1992). Job satisfaction is defined as "a pleasurable or positive emotional state resulting from the appraisal of one's job or job experience” (Locke, 1976, p. 1300). The evaluation of this experience and the consequent emotional state are primarily the result of several job dimensions, including the work itself, pay, supervision, work group, and promotion (Smith et al., 1969). However, the work itself, among several other job features, has long been regarded as the main motivator in the workplace (Saari \& Judge, 2004). Five major models help explain how job satisfaction is determined: need fulfillment, discrepancies, value attainment, equity, and disposition (see Brief, 1998, for a review).

A major reason for the strong interest in job satisfaction lies in the outcomes that it promises to deliver to the organization. Job satisfaction has been associated with organizational citizenship behavior, which consists of employee behaviors beyond the formal requirement of a job (Organ \& Ryan, 1995; Warr, 2002), absenteeism (Steel \& Rentsch, 1995), turnover (Amah, 2009; Tett \& Meyer, 1993), motivation (Kinicki et al., 2000), organizational commitment (Van Dam, 2005; Williams \& Hazer, 1986), physical health (Judge \& Hulin, 1993), and performance (Judge et al., 2001).

\section{Organizational Commitment}

Organizational commitment is generally defined as a strong desire to remain and serve the organization. As defined by Porter et al. (1974, p. 603), organizational commitment refers to "[an] individual's belief in and acceptance of the goals and values of the organization, and a strong desire to remain in an organization.” Many 
studies have examined the construct of organizational commitment over the past decades, including the antecedent and outcomes of commitment.

Research has shown that organizational commitment attitude has been related to several personal and organizational antecedents, such as age, length of service in the organization, education, job design, and supervision style (Gregersen \& Black, 1992; Luthans et al., 1987; Randall, 1993). For instance, studies have found that commitment increases with age (Hrebiniak \& Alutto, 1972). In addition, recent research has shown that modern human resource practices are an important predictor of commitment in the workplace (Agarwala, 2003; Hiltrop, 1996).

Importantly, employee commitment has been viewed as a vital area of study in light of the desirable effects it has on overall organizational effectiveness. Organizational commitment has been associated with several important outcomes, including lower turnover, job absenteeism, and higher job satisfaction, performance, and motivation (Cooper-Hakim \& Viswesvaran, 2005; De Cotiis \& Summers, 1987; Mathieu \& Zajac, 1990; Meyer \& Allen, 1997; Mowday et al., 1979; Somers, 1995). Employee absence - considered to be one of the biggest organizational problems, costing businesses billions of dollars each year (Gaudine \& Saks, 2001)—was shown to be highly related to the level of employee commitment in a recent study (Hausknecht et al., 2008).

\section{Motivation}

Motivation plays a crucial role in the success of the firm. Motivation refers to "those psychological processes that cause arousal, direction, and persistence of voluntary actions that are goal directed” (Mitchell, 1982, p. 81). Most academics agree that motivation is about energizing employees' efforts and behavior (Pinder, 1998). Corporate leaders have long pondered the idea of what motivates employees in exerting higher levels of effort. Several theoretical approaches have been put forward over the past decades to explain motivation, including need, reinforcement, cognitions, job characteristics, and lately emotions/feelings (see Kreitner \& Kinicki, 2001). In the literature, motivation is generally divided into two broad types: intrinsic and extrinsic. Intrinsic motivation involves doing something because it is inherently interesting and enjoyable to do (Ryan \& Deci, 2000). Examples include perceptions of the job as important and worthwhile. On the other hand, extrinsic motivation refers to doing something for the outcome itself. Examples might include pay and promotion. Studies have shown that employee motivation has a positive effect on performance (Abdulsalam \& Mawoli, 2012; Brownell \& McInnes, 1986). 


\section{Job Performance}

Job performance is perhaps one of the most critical factors necessary for a firm's growth and survival. According to Schermerhorn, Hunt, and Osborn (2005), job performance refers to the quantity and quality of outcomes from individual or group effort attainment. From this perspective, job performance is generally considered as the efforts exerted to achieve the desired level of outcomes that can contribute to the goals of the firm. Achieving a suitable quantity and quality of outcomes on the part of individual or group involves exerting effort and possessing abilities (e.g., McDuffie, 1995). Given the importance of job performance to organizations, numerous studies in the management literature have attempted to study the effects of certain variables on job performance. Traditional performance measures conceptualize performance as a single overall measure (Cascio, 1990); however, other academics hold that job performance is a multi-dimensional construct (Bennett, Lance, \& Woehr, 2006; Campbell et al., 1993). The latter view argues that a single measure might not capture all the components of performance measures; thus, a multi-dimensional construct of job performance is preferred. In this paper, job performance is assessed according to dimensions relating to quantity and quality (Dubinsky \& Mattson, 1979).

Based on the review thus far, the following hypotheses were developed: Hypothesis 1: Recruiter characteristics have a significant effect on job satisfaction. Hypothesis 2: Recruiter characteristics have a significant effect on commitment. Hypothesis 3: Recruiter characteristics have a significant effect on motivation. Hypothesis 4: Recruiter characteristics have a significant effect on job performance.

\section{METHODOLOGY}

The goal of this study is to determine the relationship between interviewers' characteristics and the employees' attitudes and performance during their early year(s) of work. Data were collected through a questionnaire distributed to Lebanese employees at small, medium, and large organizations.

The questionnaire comprises three main parts that contain 51 questions in total. The first part describes the demographic characteristics, including gender, age, educational level, total work experience, years of experience in current organization, sector, and position. The second part is related to the four dependent variables: job satisfaction, commitment, motivation, and job performance questions. The questions assess applicants' attitudes and performance in their first year after joining the firm. The third part of the questionnaire involves the independent variable related to the recruiters' characteristics. 


\section{Job Satisfaction}

Employee satisfaction at work was measured using eight items drawn from Brayfield and Rothe (1951), including "I feel real enjoyment in my work" and "I feel fairly satisfied with my job.” Items were rated on a five-point scale comprised of 1 (strongly agree) and 5 (strongly disagree). The measure is considered reliable and has been frequently used in recent studies involving job satisfaction (Dimotakis et al., 2011; El-Kot \& Burke, 2011; Ilies et al., 2006; Mount et al., 2006). The coefficient alpha was 0.9 .

\section{Job Motivation}

Seven items drawn from Hackman and Oldham (1975) were used to measure applicants' motivation. Sample items include "the work I do is interesting” and "I have a coach who keeps me motivated." Similar items have been used in recent job motivation research. All items were scored on a five-point scale ranging from 1 (strongly agree) to 5 (strongly disagree). The coefficient alpha was 0.71 .

\section{Organizational Commitment}

Organizational commitment was assessed using eight items (Cook \& Wall, 1980). Examples include "I am quite proud to be able to tell people who it is I work for" and "the offer of a bit more money with another employer would not seriously make me think of changing my job.” Items were rated on a five-point scale from 1 (strongly agree) to 5 (strongly disagree). The coefficient alpha was 0.55 .

\section{Job Performance}

Job performance was measured using a recently modified version (Singh et al., 1996) of a self-rating scale originally developed by Pruden and Reese (1972). Seven items were used to assess job performance in terms of quality and quantity of work (e.g., Dubinsky \& Mattson, 1979), including "how do you rate yourself in terms of the quantity of work you accomplish" and "how do you rate yourself in terms of the quality of your relations with your clients." All items were rated on a five-point scale ranging from 1 (strongly agree) to 5 (strongly disagree). The coefficient alpha was 0.73

\section{Recruiters' Characteristics}

The independent variable - that is, recruiters' characteristics — was measured using 20 items adopted from Schmitt and Coyle (1976) involving five major dimensions: empathy (four items; sample items are "the interviewer has a warm personality" and "the interview was cooperative”), manner (four items; sample items 
are "the interviewer interrupted you" and "the interviewer was irritable"), aggressive (four items; sample items are "the interviewer was aggressive" and "the interviewer was stubborn"), correctness (four items; sample items are "the interviewer was capable of answering questions" and "the interviewer had broad knowledge”), and job information (four items; sample items are "the interviewer informed me that high salary is a possibility" and "the interviewer gave information about supervision”). All items were scored on a five-point scale ranging from 1 (strongly agree) to 5 (strongly disagree). The scale has good reliability (see, for example, Schmitt \& Coyle, 1976) and has been used in recent research on recruiters' characteristics (Carless \& Imber, 2007). In this study, the five dimensions on the scale each had a coefficient alpha ranging from 0.77 to 0.9 .

\section{Demographic Information}

\section{RESULTS}

Respondents were almost equally distributed by gender (47\% male, 53\% female). Furthermore, $47 \%$ of the respondents were between 20 and 30 years old while 32\% were between 31 and 40. Regarding their education, 48\% had earned a bachelor's degree $47 \%$ had earned a master's degree. In addition, $72 \%$ of the respondents came from the public sector. With respect to their experience, $60 \%$ of the participants had between 16 and 25 years of experience. Most of the surveyed individuals held administrative positions (55\%).

\section{Quantitative Analysis}

The authors tested the relationship between recruiters' characteristics and the hired employees' attitudes and performance during their initial years of work. In particular, the authors attempted to examine the effect of the interviewer's job information, aggressive dimension, manner, and empathy dimension on employees' job satisfaction, motivation, commitment, and job performance after joining the firm. A regression analysis was performed to test the following hypotheses:

$\mathrm{H} 1$ : Interviewer characteristics factors have a significant effect on job satisfaction

The following relationship was discovered:

Job satisfaction $=1.309+0.125 *$ empathic dimension $+0.216 *$ correctness $+0.121 *$ job_info

At the 5\% level of significance, the regression analysis showed that the dimensions related to correctness, empathy, and job information demonstrate a significant positive effect on job satisfaction. On the other hand, both the aggressive and manner dimensions had no significant effect on the dependent variable. Based on 
the results, correctness made the strongest unique contribution to the dependent variable (beta $=.356$ ). Results of the regression analysis provided support for Hypothesis 1 . Beta coefficients for the five dimensions were correctness, beta $=.356, t$ $=4.583, p<.001$; empathy, beta $=243, t=3.713, p<.001$; job information, beta $=.173, t=2.256, p=.025$; aggressive, beta $=.040, t=699, p=.485$, n.s.; and manner, beta $=0, t=-.006, p=.995$, n.s.

Coefficients $^{\mathrm{a}}$

\begin{tabular}{|c|c|c|c|c|c|}
\hline \multirow[b]{2}{*}{ Model } & \multicolumn{2}{|c|}{$\begin{array}{l}\text { Unstandardized } \\
\text { Coefficients }\end{array}$} & \multirow{2}{*}{$\begin{array}{c}\text { Standardized } \\
\text { Coefficients }\end{array}$} & \multirow[b]{2}{*}{$\mathrm{t}$} & \multirow[b]{2}{*}{ Sig. } \\
\hline & B & Std. Error & & & \\
\hline 1 (Constant) & 1.309 & .231 & & 5.661 & .000 \\
\hline empathic_dimension & .125 & .034 & .243 & 3.713 & .000 \\
\hline manner & .000 & .042 & .000 & -.006 & .995 \\
\hline aggressive_dimension & .030 & .044 & .040 & 699 & .485 \\
\hline correctness & .216 & .047 & .356 & 4.583 & .000 \\
\hline job_info & .121 & .053 & .173 & 2.256 & .025 \\
\hline
\end{tabular}

a. Dependent Variable: job_satisfaction

H2: Interviewer characteristics factors have a significant effect on employee motivation

The following relationship was discovered:

Motivation $=1.622+0.16 *$ empathic dimension $-0.116 *$ manner $+0.242 *$ correctness

\begin{tabular}{|l|c|c|c|c|c|}
\multicolumn{1}{|c|}{ Model } & \multicolumn{2}{|c|}{$\begin{array}{c}\text { Coefficients } \\
\text { Unstandardized } \\
\text { Coefficients }\end{array}$} & $\begin{array}{c}\text { Standardized } \\
\text { Coefficients }\end{array}$ & & \\
\cline { 2 - 6 } \multicolumn{1}{|c|}{ B } & B & Std. Error & Beta & $\mathrm{t}$ & Sig. \\
\hline 1 (Constant) & 1.622 & .257 & & 6.308 & .000 \\
empathic_dimension & .161 & .038 & .280 & 4.278 & .000 \\
manner & -.116 & .047 & -.153 & -2.492 & .014 \\
aggressive_dimension & .083 & .048 & .099 & 1.718 & .087 \\
correctness & .242 & .052 & .358 & 4.606 & .000 \\
job_info & .025 & .059 & .032 & .414 & .679 \\
\hline
\end{tabular}

a. Dependent Variable: motivation

At the $5 \%$ level of significance, the regression analysis demonstrated that the dimensions related to correctness, empathy, and manners had a significant effect on 
job motivation, while the job information and aggressive dimensions of the interviewer had no effect on the dependent variable. The findings showed support for Hypothesis 2. Beta coefficients for the five dimensions were correctness, beta $=.358, t$ $=4.606, p<.001$; empathy, beta $=.280, t=4.278, p<.001$; manner, beta $=-.153, t=$ -2.492, $p=.014$; aggressive, beta $=.099, t=1.718, p=.087$, n.s.; and job information, beta $=.032, t=.414, p=.679$, n.s.

H3: Interviewer characteristics factors have a significant effect on employee commitment

As shown below at 5\% level of significance, none of the recruiter's dimensions had an effect on employee commitment, rendering $\mathrm{H} 3$ to be rejected.

\section{Coefficients $^{\mathrm{a}}$}

\begin{tabular}{|c|c|c|c|c|c|}
\hline \multirow[b]{2}{*}{ Model } & \multicolumn{2}{|c|}{$\begin{array}{l}\text { Unstandardized } \\
\text { Coefficients }\end{array}$} & \multirow{2}{*}{$\begin{array}{c}\text { Standardized } \\
\text { Coefficients } \\
\text { Beta }\end{array}$} & \multirow{3}{*}{$\begin{array}{c}t \\
8.560\end{array}$} & \multirow{3}{*}{$\begin{array}{l}\text { Sig. } \\
.000\end{array}$} \\
\hline & $\mathrm{B}$ & Std. Error & & & \\
\hline 1 (Constant) & 2.786 & .325 & & & \\
\hline empathic_dimension & .022 & .048 & .040 & .472 & .638 \\
\hline manner & .052 & .059 & .070 & .886 & .377 \\
\hline aggressive_dimension & .036 & .061 & .043 & .582 & .561 \\
\hline correctness & -.020 & .066 & -.030 & -.302 & .763 \\
\hline job_info & -.056 & .075 & -.074 & -.745 & .457 \\
\hline
\end{tabular}

a. Dependent Variable: commitment

H4: Interviewer characteristics factors have a significant effect on job performance

The following relationship was discovered:

Job performance $=1.571+0.281 *$ empathic dimension $-0.161 *$ manner $0.152 *$ aggressive dimension $+0.249 *$ correctness

At the $5 \%$ level of significance, the regression results indicated that several of the recruiters' dimensions have a significant positive effect on job performance. In particular, the empathy dimension and correctness demonstrated a positive relationship with performance, while the manner and aggressive dimensions of the interviewer confirmed a negative relationship with job performance. Job information had no effect on job performance. The empathy dimension made the strongest unique contribution to job performance. Overall, the findings supported Hypothesis 4. Beta coefficients for the five dimensions were empathy, beta $=.379, t=6.511, p<.001$; 
correctness, beta $=.286, t=4.140, p<.001$; aggressive, beta $=-.141, t=-2.735, p$ $=.007$; manner, beta $=-.164, t=-3.003, p=.003$; and job information, beta $=.114, t=$ $1.669, p=.097$ n.s.

\section{Coefficients $^{\mathrm{a}}$}

\begin{tabular}{|c|c|c|c|c|c|c|}
\hline \multirow{2}{*}{\multicolumn{2}{|c|}{ Model }} & \multicolumn{2}{|c|}{$\begin{array}{l}\text { Unstandardized } \\
\text { Coefficients }\end{array}$} & \multirow{2}{*}{$\begin{array}{c}\text { Standardized } \\
\text { Coefficients } \\
\text { Beta }\end{array}$} & \multirow[b]{2}{*}{$\mathrm{T}$} & \multirow[b]{2}{*}{ Sig. } \\
\hline & & B & Std. Error & & & \\
\hline \multirow[t]{6}{*}{1} & (Constant) & 1.571 & .295 & & 5.328 & .000 \\
\hline & empathic_dimension & .281 & .043 & .379 & 6.511 & .000 \\
\hline & manner & -.161 & .054 & -.164 & -3.003 & .003 \\
\hline & aggressive_dimension & -.152 & .056 & -.141 & -2.735 & .007 \\
\hline & correctness & .249 & .060 & .286 & 4.140 & .000 \\
\hline & job_info & .114 & .068 & .114 & 1.669 & .097 \\
\hline
\end{tabular}

a. Dependent Variable: job_performance

\section{DISCUSSION AND CONCLUSION}

The results of this study confirm the importance of recruiters' characteristics and their relationship with important organizational outcomes. Previous research has established that the recruiter plays an important role in applicants' overall impressions of the firm and intentions to accept the job offer (Harris \& Fink, 1987). The current research extended this area of study to applicants' reactions after they join the firm. The results provided direct support to Hypotheses 1, 2, and 4, but failed to support Hypothesis 3. In other words, recruiter characteristics have a significant effect on job satisfaction, motivation, and job performance respectively, but no effect on commitment.

Regarding Hypothesis 1, compared to other characteristics, correctness (competence of the interviewer) had the strongest effect on job satisfaction. Based on the results, applicants who view their recruiters as personally competent tend to be satisfied when they join the firm. Based on the signaling theory, perceptions of competent recruiters might spill over to perceptions of the organization itself as a competent organization. Working for a competent organization might increase employees' self-esteem, which could lead to job satisfaction at the workplace (e.g., Alavi \& Askaripur, 2003; Nurullah, 2010). Moreover, recruiters' empathy or demonstration of a personal understanding of the applicant during the interview also seemed to play a role, albeit to a lower extent than recruiters' competence. The findings indicated that applicants like recruiters who can empathize with them 
(Schmitt \& Coyle, 1976) and might therefore contribute to their overall job satisfaction when they are hired. Empathy seems to be an important predictor of positive employee attitudes (Scott et al., 2010). Finally, job information was also found to be related to job satisfaction. It could be said that interviewers who provide ample information to job applicants can reduce anxiety associated with the lack of information and thereby increase satisfaction when job applicants start working in the firm.

With respect to Hypothesis 2, it was also interesting to determine that recruiter correctness made the largest contribution to motivation, again followed by empathy. The results indicate that employees felt highly motivated after joining the firm when they believed that they were interviewed by a competent and an understanding recruiter. Working for a competent employer might increase their self-confidence and -esteem, which could result in higher motivation. Moreover, based on the social exchange theory (Blau, 1964), employees who perceived that the recruiter understood and was supportive of their feelings and emotions reciprocated with higher levels of motivation in the workplace (e.g., Eisenberger et al., 1990; Rhoades \& Eisenberger, 2002). On the other hand, when recruiters displayed negative manners during the interview, it had a negative impact on motivation. Recruiters who were unprofessional when conducting the interview, such as engaging in repeated interruptions, served to decrease employees' motivation when they started work.

With respect to commitment, contrary to expectations, recruiters' characteristics seemed to be unconnected with organizational commitment. None of the recruiters' characteristics were significant. One reason for this might be that organizational commitment is more of a long-term investment. In general, tenure tends to be positively correlated with organizational commitment (Allen \& Meyer, 1993; Angle \& Perry, 1981; Mathieu \& Zajac, 1990). The longer workers remain in the organization, the more they might become attached to their organization (Meyer \& Allen, 1984; Mowday et al., 1982). In this study, the authors measured commitment in the first year, which might explain the lack of statistical significance. Future research can investigate the outcomes of recruiters' characteristics on organizational commitment in subsequent years.

Finally, the results suggest that recruiters' characteristics tend to be an important factor for employees' job performance (e.g., Gilliland, 1993). In particular, among several recruiter characteristics, empathy seemed to have the biggest effect on job performance. In other words, recruiters who had a pleasant personality motivated employees to perform better in terms of quality and quantity at the workplace. Based on the signaling theory and social exchange theory, perceiving the organization as 
friendly and supportive stimulated employees in reciprocating with better performance at the workplace. In addition, recruiters' correctness also had an impact on job performance. However, recruiters who were viewed as having aggressive and irritating manners during the interview had a negative effect on performance. It seems that workers are negatively affected by such recruiters and might actually translate these perceptions into lower performance on the job according to the results attained here.

This study aims to increase our understanding of the relationship between the recruiter and employees' attitudes and behavior after joining the firm. It also makes a significant contribution to the body of knowledge related to the field. The study showed that recruiters have a significant impact on employees' attitudes and performance. Recruiters have a critical role to play in job satisfaction, motivation, and performance of newly hired people. Overall, the results demonstrate that employers interested in having a satisfied, motivated, and well-performing workforce are advised to hire recruiters who are competent, friendly, and able to furnish ample information about the job itself. The role of employee selection and training is critical in hiring and training recruiters according to the standards identified in this study.

According to the results attained here, firms are advised to select recruiters who possess personal competence while exhibiting a friendly attitude. Recruiters should be competent or well-experienced in the field as it seems from the study that competent recruiters who have broad knowledge in the industry have a desirable impact on applicants. Experienced individuals with broad knowledge and experience appear to be a key selection criterion when hiring recruiters.

The findings here also demonstrate the importance of selecting recruiters with a friendly personality. It is recommended that firms invest in selection tests, which can identify recruiters with a warm character who can empathize with applicants and show a high level of understanding. It appears that applicants value recruiters who are cooperative and understanding, and this subsequently affects their attitudes and performance after they join the firm, which is in line with the results of the study.

Moreover, according to the findings of the study, employers should thoroughly inform them about the different jobs in the company that enable them to develop a good understanding of all aspects of the jobs in the firm. This might include detailed information on salaries, benefits, job tasks and activities, supervision style, and available growth opportunities. The desired goal of training here is to develop recruiters who are able to provide applicants with complete detailed information about the elements of the job during the interview. 
As all studies, there are several limitations that should be mentioned. The first limitation is related to the relatively small sample size. The researchers recommend using larger sample sizes, which can further boost confidence in the results attained. Moreover, the fact that most (72\%) of the respondents came from the public sector could limit generalization to other sectors. Future studies that can ensure a balanced mix of both public and private sector are therefore necessary. Finally, performance measures in this study relied on self-report measures rather than objective measures. Although self-report measures are widely used in research and are considered valid (Wall et al., 2004), future research can include objective measures when feasible to strengthen the findings of the study.

\section{REFERENCES}

Abdulsalam, D., \& Mawoli, M. (2012). Motivation and Job Performance of Academic Staff of State Universities in Nigeria: The Case of Ibrahim Badamasi Babangida University, Lapai, Niger State. International Journal of Business and Management, 7(14), 142-148. http://dx.doi.org/10.5539/ijbm.v7n14p142

Agarwala, T. (2003). Innovative human resource practices and organizational commitment: An empirical investigation. International Journal of Human Resource Management, 14(2), 175-197. http://dx.doi.org/10.1080/0958519021000029072

Alavi, H. R., \& Askaripur, M. R. (2003). The relationship between self-esteem and job satisfaction of personnel in government organizations. Public Personnel Management, 32(4), 591-600.

Allen, N. J., \& Meyer, J. P. (1993). Organizational commitment: Evidence of career stage effect. Journal of Business Research, 26, 49-61. http://dx.doi.org/10.1016/0148-2963(93)90042-N

Amah, O. E. (2009). Job satisfaction and turnover intention relationship: the moderating effect of job role centrality and life satisfaction. Research and Practice in Human Resource Management, 17(1), 24-35.

Angle, H. L., \& Perry, J. L. (1981). An empirical assessment of organizational commitment and organizational effectiveness. Administrative Science Quarterly, 26, 1-13. http://dx.doi.org/10.2307/2392596

Bennett, W., Jr., Lance, C., \& Woehr, D. (2006). Performance measurement: Current perspectives and future challenges. Mahwah, NJ: Erlbaum.

Blau, G., \& Boal, K. (1987). Conceptualizing how job involvement and organizational commitment affect turnover and absenteeism. Academy of Management Review, 12(2), 288-300. http://dx.doi.org/10.2307/258536 
Blau, P. (1964). Exchange and Power in Social Life. New York, NY: Wiley.

Brayfield A. H., \& Rothe H. F. (1951). An index of job satisfaction. Journal of Applied Psychology, 35, 307-311. http://dx.doi.org/10.1037/h0055617

Brief, A. P. (1998). Attitudes in and around organizations. Thousand Oaks, CA: Sage.

Brownell, P., \& McInnes, M. (1986), Budgetary Participation, Motivation and Managerial Performance. The Accounting Review, 67(4), 587-600.

Campbell, J. P., McCloy, R. A., Oppler, S. H., \& Sager, C. E.(1993). A theory of performance. In N. Schmitt and W.C. Borman and Associates (Eds.), Personnel selection in organizations (pp. 35-69). San Francisco, CA: Jossey-Bass.

Cascio, W. F. (1990). Managing Human Resources: Productivity, Quality of work life, Profits. New York, NY: McGraw-Hill.

Carless, S. A., \& Imber, A. (2007). The influence of perceived interviewer and job and organizational characteristics on applicant attraction and job choice intentions: The role of applicant anxiety. International Journal of Selection and Assessment, 15(4), 359-371. http://dx.doi.org/10.1111/j.1468-2389.2007.00395.x

Chapman, D. S., Uggerslev, K. L., Carroll, S. A., Piasentin, K. A., \& Jones, D. A. (2005). Applicant attraction to organizations and job choice: A meta-analytic review of the correlates of recruiting outcomes. Journal of Applied Psychology, 90, 928-944. http://dx.doi.org/10.1037/0021-9010.90.5.928

Cook, J., \& Wall, T. (1980). New work attitude measures of trust, organizational commitment and personal need non-fulfillment. Journal of Occupational Psychology, 53, 39-52. http://dx.doi.org/10.1111/j.2044-8325.1980.tb00005.x

Cooper-Hakim, A., \& Viswesvaran, C. (2005). The construct of work commitment: Testing an integrative framework. Psychological Bulletin, 131(2), 241-259. http://dx.doi.org/10.1037/0033-2909.131.2.241

Cranny, C. J., Smith, R. C., \& Stone, E. F. (1992). Job satisfaction: How people feel about their jobs and how it affects their performance. New York, NY: Lexington Smart.

DeCotiis, T., \& Summers, T. (1987). A path analysis of a model of the antecedents and consequences of organizational commitment. Human Relations, 40(7), 44570. http://dx.doi.org/10.1177/001872678704000704

Dimotakis, N., Scott, B., \& Koopman, J., (2011). An experience sampling investigation of workplace interactions, affective states, and employee well-being. Journal of Organizational Behavior, 32, 572-588. http://dx.doi.org/10.1002/job.722 
Dubinsky, A. J., \& Mattson, B. E. (1979). Consequences of role conflict and ambiguity experienced by retail salespeople. Journal of Retailing, 55(Winter), 70-86.

Eisenberger, R., Fasolo, P., \& Davis-LaMastro, V. (1990). Perceived organizational support and employee diligence, commitment, and innovation. Journal of Applied Psychology, 75, 51-59. http://dx.doi.org/10.1037//0021-9010.75.1.51

El-Kot, G. \& Burke, R. (2011). Job stressors, supervisory support and work outcomes among Egyptian managers. Review of Management, 1(4): 10-24.

Gaudine, A., and A. Saks (2001). Effects of an absenteeism feedback intervention on employee absence behaviors. Journal of Organizational Behavior 22, 15-29. http://dx.doi.org/10.1002/job.73

Gilliland, S. W. (1993). The perceived fairness of selection systems: An organizational perspective. Academy of Management Review, 18(4), 694-734. http://dx.doi.org/10.2307/258595

Gilliland, S. W. (1994). Effects of procedural and distributive justice on reactions to a selection system. Journal of Applied Psychology, 79, 117-127. http://dx.doi.org/10.1037/0021-9010.79.5.691

Goltz, S. M., \& Giannantonio, C. M. (1995). Recruiter Friendliness and Attraction to the Job: The Mediating Role of Inferences about the Organization. Journal of Vocational Behavior, 46, 109-118. http://dx.doi.org/10.1006/jvbe.1995.1007

Gregersen, H. B., \& Black, J. S. (1992). Antecedents to commitment to a parent company and a foreign operation. Academy of Management Journal, 35, 65 - 90. http://dx.doi.org/10.2307/256473

Hackman, J. R. \& Oldham, G. R. (1975). Development of the job diagnostic survey. Journal of Applied Psychology, 60 (April), 159-170. http://dx.doi.org/10.1037/h0076546

Hannah, D. R., \& Iverson, R. D. (2004). Employment relationships in context: implications for policy and practice. In Coyle-Shapiro, J., Shore, L., Taylor, M.S. and Tetrick, L. (Eds.), The Employment Relationship: Examining the Psychological and Contextual Perspectives (pp. 332-501). Oxford, England: Oxford University Press.

Harris, M. M., \& Fink, L. S. (1987). A field study of applicant reactions to employment opportunities: Does the recruiter make a difference. Personnel Psychology, 40, 765-784. http://dx.doi.org/10.1111/j.1744-6570.1987.tb00623.x

Hausknecht, J. P., Day, D. V., \& Thomas S. C. (2004). Applicant reactions to selection procedures: An updated model and meta-analysis. Personnel Psychology, 57(3), 639-683. http://dx.doi.org/10.1111/j.1744-6570.2004.00003.x 
Hausknecht, J. P., Hiller, N. J., \& Vance, R. J. (2008). Work unit absenteeism: Effects of satisfaction, commitment, labor market conditions, and time. Academy of Management Journal, 51(6), 1223-1245. http://dx.doi.org/10.5465/AMJ.2008.35733022

Hiltrop, J. M. (1996). Managing the changing psychological contract. Employee Relations, 18(1), 36-49. http://dx.doi.org/10.1108/01425459610110227

Hrebiniak, L. G., \& Alutto, J. A. (1972). Personal and Role-related factors in the Development of Organizational Commitment. Administrative Science Quarterly, 17, 555-572. http://dx.doi.org/10.2307/2393833

Ilies, R., Scott, B., \& Judge, T. (2006) The interactive effects of personal traits and experienced states on intraindividual patterns of citizenship behavior. Academy of Management Journal, 49(3): 561-575. http://dx.doi.org/10.5465/AMJ.2006.21794672

Imus, A. L., \& Ryan, A. M. (2005). Relevance and rigor in research on the applicant's perspective: In pursuit of pragmatic science. In A. Evers, N. Anderson and O. Voskuijl (Eds.), Handbook of Selection (pp. 280-296). Oxford, UK: Blackwell.

Judge, T. A., \& Hulin, C. L. (1993). Job satisfaction as a reflection of disposition: A Multiple source causal analysis. Organizational Behavior and Human Decision Processes, 56, 388-421. http://dx.doi.org/10.1006/obhd.1993.1061

Judge, T. A., Thoresen, C. J., Bono, J. E., \& Patton, G. K. (2001). The job satisfaction-job performance relationship: A qualitative and quantitative review. Psychological Bulletin, 127, 376 - 407. http://dx.doi.org/10.1037//00332909.127.3.376

Kinicki, A. J., Prussia, G. E., \& McKee-Ryan, F. M. (2000). A panel study of coping with involuntary job loss. The Academy of Management Journal, 43(1), 90-100. http://dx.doi.org/10.2307/1556388

Kreitner, R., \& Kinicki, A. (2001). Organizational Behavior. (5th ed). New York, NY: McGraw Hill.

Locke E. A. (1976). The Nature and Causes of Job Satisfaction. In M.P.Dunnette (Ed), Handbook of Industrial and Organizational Psychology Chicago (pp. 12971350). IL: Rand McNally.

Luthans, F., Baack, D., \& Taylor, L. (1987). Organizational commitment: analysis of antecedents. Human Relations, 40, 219-236. http://dx.doi.org/10.1177/001872678704000403

Mathieu, J. E., \& Zajac, D.M. (1990). A review and meta-analysis of the antecedents, correlates, and consequences of organizational commitment. Psychological Bulletin, 108, 171-194. http://dx.doi.org/10.1037/0033-2909.108.2.171 
McDuffie, J.P. (1995). Human resource bundles and manufacturing performance: organizational logic and flexible production systems in the world auto industry. Industrial and Labor Relations Review, 48 (2), 197-213. http://dx.doi.org/10.2307/2524483

Meyer, J. P., \& Allen, N. J. (1984). Testing the "'Side-Bet Theory” of organizational commitment: some methodological considerations. Journal of Applied Psychology, 69, 372-378. http://dx.doi.org/10.1037/0021-9010.69.3.372

Meyer, J. P., \& Allen, N. J. (1997). Commitment in the Workplace. Thousand Oaks, CA: Sage.

Michaels, E., Handfield-Jones, H., \& Axelrod, B. (2001). The War for Talent. Boston, Mass: Harvard Business School Press.

Mitchell, T. (1982). Motivation: New directions for theory, research and practice. Academy of Management review, 7(1), 80-88. http://dx.doi.org/10.5465/AMR.1982.4285467

Mount, M, Ilies, R., \&, Johnson, E. (2006). Relationship of personality traits and counterproductive work behaviors: the mediating effects of job satisfaction. Personnel Psychology, 59(3), 591-622. http://dx.doi.org/10.1111/j.17446570.2006.00048.x

Mowday, R. T., Steers, R. M., \& Porter, L. W. (1979). The measurement of organizational commitment. Journal of Vocational Behavior, 14, 227-247. http://dx.doi.org/10.1016/0001-8791(79)90072-1

Mowday, R. T., Porter, L. W., \& Steers, R. M. (1982). Employee-organization Linkages: The psychology of commitment and turnover. Academic Press: New York: NY.

Nurullah, A. S. (2010). Predictors of job satisfaction among emerging adults in Alberta, Canada. International Journal of Business and Management, 5(3), 3-15.

Odiorne, G. S., \& Hann, A. S. (1961). Effective college recruiting. Bureau of Industrial Relations, University of Michigan. Ann Arbor. University of Michigan.

Organ, D. W., \& Ryan, K. (1995). A meta-analytic review of attitudinal and dispositional predictors of organizational citizenship behavior. Personnel Psychology, 48, 775-802. http://dx.doi.org/10.1111/j.1744-6570.1995.tb01781.x

Pinder C. C. (1998). Work Motivation in Organizational Behavior. Upper Saddle River, NJ: Prentice Hall.

Porter, L. W., Steers, R. M., Mowday, R. T., \& Boulian, P. V. (1974). Organizational Commitment, Job Satisfaction, and Turnover among Psychiatric Technicians. Journal of Applied Psychology, 59, 603-609. http://dx.doi.org/10.1037/h0037335 
Posthuma, R. A., Morgeson, F. P., \& Campion, M. A. (2002). Beyond employment interview validity: A comprehensive narrative review of recent research and trends over time. Personnel Psychology, 55, 81-101. http://dx.doi.org/10.1111/j.1744-6570.2002.tb00103.x

Pruden, H., \& Reese, R. (1972). Interorganizational role-set relations and the performance and satisfaction of industrial salesmen. Administrative Science Quarterly, 17, 601-609.

Randall, D M. (1993). Cross-cultural research on organizational commitment: A review and application of Hofstede's value survey module. Journal of Business Research, 26, 91-110. http://dx.doi.org/10.1016/0148-2963(93)90045-Q

Rhoades, L., \& Eisenberger, R. (2002). Perceived organizational support: A Review of the Literature. Journal of Applied Psychology, 87(4), 698-714. http://dx.doi.org/10.1037/0021-9010.87.4.698

Robertson, I. T., Iles, P. A., Gratton, L. \& Sharpley, D. (1991). The impact of personnel selection and assessment methods on candidates. Human Relations, 44, 963-982. http://dx.doi.org/10.1177/001872679104400904

Rynes, S. L. \& Miller, H. E. (1983). Recruiter and job influences on candidates for Employment. Journal of Applied Psychology, 68, 147-54. http://dx.doi.org/10.1037//0021-9010.68.1.147

Ryan, R. M. \& Deci, E. L. (2000). Self-determination theory and the facilitation of intrinsic motivation, social development, and well-being. American Psychologist, 55 (1), 68-78. http://dx.doi.org/10.1037/0003-066X.55.1.68

Rynes, S. L., Bretz, R. D., \& Gerhart, B. (1991). The importance of recruitment in job choice: A different way of looking. Personnel Psychology, 44, 512-487.

Saari, L. M., \& Judge, T. A. (2004). Employee Attitudes and Job Satisfaction. Human Resource Management, 43(4), 395-407.

Scott, B. A., Colquitt, J. A., Paddock, E. L., \& Judge, T. A. (2010). A daily investigation of the role of manager empathy on employee well-being. Organizational Behavior And Human Decision Processes, 113, 127-14.

Schermerhorn, J. R., Hunt, J. G., \& Osborn, R. N. (2005). Organizational Behavior (9th ed.). New York, NY: John Wiley and Sons, Inc.

Schmitt, N., \& Coyle, B. (1976). Applicant decisions in the employment interview. Journal of Applied Psychology, 61(2), 184-192. http://dx.doi.org/10.1037//00219010.61.2.184

Shore, L. M., \& Wayne, S. J. (1993). Commitment and employee behavior: comparison of affective commitment and continuance commitment with 
perceived organizational support. Journal of Applied Psychology, 78, 774-780. http://dx.doi.org/10.1037/0021-9010.78.5.774

Singh, J., Verbeke, W., \& Rhoads, G.K. (1996). Do organizational practices matter in role stress processes: a study of direct and moderating effects for marketingoriented boundary spanners. Journal of Marketing, 60(3), 69-86. http://dx.doi.org/10.2307/1251842

Smart, Bradford D. (1999), Topgrading: How Leading Companies Win by Hiring, Coaching and Keeping the Best People. New York, NY: Prentice Hall Art.

Smith, P. C., Kendall, L. M., \& Hulin, C. L. (1969). The measurement of satisfaction in work and retirement. Chicago: Rand McNally.

Somers, M. J. (1995). Organizational commitment, turnover and absenteeism: an examination of direct and interaction effects. Journal of Organizational Behavior, 15(1), 49-58. http://dx.doi.org/10.1002/job.4030160107

Spence, A. M. (1973). Job market signaling. Quarterly Journal of Economics, 87(3), 355-374.

Steel, R. P., \& Rentsch, J. R. (1995). Influence of cumulation strategies on the long range prediction of absenteeism. Academy of Management Journal, 38(6), 16161634. http://dx.doi.org/10.2307/256846

Taylor, M. S., \& Bergmann, T. J. (1987). Organizational recruitment activities and applicants' reactions at different stages of the recruitment process. Personnel Psychology, 40, 261-85. http://dx.doi.org/10.1111/j.1744-6570.1987.tb00604.x

Tett, R. P., \& Meyer, J. P. (1993). Job satisfaction, organizational commitment, turnover intention: Path analysis based on meta-analytic findings. Personnel Psychology, 46, 259-293.

Turban, D. B., \& Dougherty, T. W. (1992). Influences of campus recruiting on applicant attraction to the firm. Academy of Management Journal, 35, 739-765. http://dx.doi.org/10.2307/256314

Van Dam, K. (2005). Employee attitudes toward job changes: An application and extension of Rusbult and Farrell's investment model. Journal of Occupational \& Organizational Psychology, 78(2), 253-272.

Wall, T. D., Michie, J., Patterson, M., Wood, S., Sheehan, M., Clegg, C. W., \& West, M. (2004) .On the validity of subjective measures of company performance. Personnel Psychology, 57, 118- 95. http://dx.doi.org/10.1111/j.17446570.2004.tb02485.x

Warr, P. B. (2002). Psychology at Work (5th edition). Harmondsworth: Penguin

Williams, L. J., \& Hazer, J. T. (1986). Antecedents and consequences of satisfaction and commitment in turnover models: A reanalysis using latent variable structural 
equation methods. Journal of Applied Psychology, 71, 219-231. http://dx.doi.org/10.1037/0021-9010.71.2.219 